\title{
Hubungan Usia dan Paritas dengan Kejadian Preeklampsia Berat di Rumah Sakit Achmad Mochtar Bukittinggi Tahun 2012 - 2013
}

\author{
Siqbal Karta Asmana ${ }^{1}$, Syahredi ${ }^{2}$, Noza Hilbertina ${ }^{3}$
}

\begin{abstract}
Abstrak
Preeklampsia dapat menimbulkan berbagai komplikasi yang membahayakan bagi ibu dan janin, sehingga dapat menimbulkan kematian. Beberapa faktor risiko seperti usia yang ekstrem ( $<20 \&>35$ tahun) dan nuliparitas. Keduanya merupakan faktor risiko yang tidak dapat dimodifikasi. Tujuan penelitian ini adalah menentukan hubungan usia dan paritas dengan kejadian preeklampsia berat. Telah dilakukan penelitian di Bagian Rekam Medis Rumah Sakit Achmad Mochtar Bukittinggi terhadap data semua pasien rawat inap obstetri dan ginekologi tahun 2012 - 2013. Penelitian menggunakan metode analitik dengan desain cross sectional study. Analisis penelitian menggunakan ratio prevalence dan chi-square test dengan derajat kepercayaan 95\%. Penelitian ini menemukan 162 kasus (4,99\%) preeklampsia berat. Proporsi kasus terbesar ditemukan pada kelompok usia ekstrem $(9,90 \%)$ dan kelompok multiparitas (8,68\%). Analisis ratio prevalence menyimpulkan bahwa usia ekstrem merupakan faktor risiko preeklampsia berat $(\mathrm{RP}=1,476 ; \mathrm{Cl}=1,094-1,922)$, dan nuliparitas belum dapat ditentukan apakah merupakan faktor risiko atau faktor protektif $(\mathrm{RP}=0,765 ; \mathrm{Cl}=0,565-1,034)$. Berdasarkan analisis dengan chi-square test, disimpulkan bahwa terdapat hubungan yang bermakna antara usia dengan preeklampsia berat $(p=0,014<0,05)$ dan tidak terdapat hubungan yang bermakna antara paritas dengan preeklampsia berat $(p=0,096>0,05)$.
\end{abstract}

Kata kunci: preeklampsia, faktor risiko, usia, paritas

\section{Abstract}

Preeclampsia can cause the complication that endanger maternal and fetal, until death. There are many risk factors like extreme age (<20 \& $>35$ years) and nuliparity that can not modify. The objective of this study was to determine the relationship of maternal age and parity to the incidence of severe preeclampsia. The research conducted at Medical Record Division of Achmad Mochtar Hospital Bukittinggi about data of all hospitalized patients of obstetrics and gynecology on 2012 - 2013. This research used the analytical method with cross sectional study. Analysis of this research used ratio prevalence and chi-square test with degree of confidence 95\%. This research found 162 case (4.99\%) severe preeclampsia. The highest proportion of this case was the extreme age groups (9.90\%) and multiparity group (8.68\%). Analysis with the ratio prevalence concluded that extreme age is a risk factor for severe preeclampsia $(R P=1.476 ; C l=1.094$ - 1.922) and nuliparity can not determined wheather a risk factor or protective factor $(R P=0.765 ; C l=0.565-1.034)$. Analysis with chi-square test concluded that there is a significant relationship between age with severe preeclampsia $(p=0.014<0.05)$ and there is no significant relationship between parity with severe preeclampsia $(p=0.096>0.05)$.

Keywords: preeclampsia, risk factors, age, parity

Affiliasi penulis: 1. Prodi Profesi Dokter FK UNAND (Fakultas Kedokteran Universitas Andalas Padang), 2. Bagian Obstetri dan Ginekologi FK UNAND/RSUP Dr. M. Djamil Padang, 3. Bagian Patologi Anatomi FK UNAND
Korespondensi: Siqbal Karta Asmana, Email: si_kar_as@yahoo.com, Telp: 082284632460 


\section{PENDAHULUAN}

Preeklampsia sampai saat ini masih menjadi masalah yang mengancam dalam kehamilan, terutama di negara berkembang. ${ }^{1} \quad$ Penyakit preeklampsia ini merupakan penyebab utama kematian maternal di dunia. ${ }^{2}$ Sebuah penelitian memperkirakan bahwa insiden preeklampsia di dunia berkisar antara $2 \%-10 \%$, di Amerika Utara dan Eropa sebesar $5-7$ kasus per 10.000 kelahiran, di Afrika Utara, Mesir, Tanzania dan Ethiopia berkisar antara $1,8 \%-7,1 \%$ dan di Nigeria berkisar antara $2 \%-16,7 \% .{ }^{1}$ Prevalensi preeklampsia di Jerman pada tahun 2006 adalah 2,31\%. ${ }^{3}$ Di United States terjadi peningkatan prevalensi dari 3,4\% pada tahun 1980 menjadi 3,8\% pada tahun $2010 .{ }^{4} \mathrm{Di}$ Indonesia, pada tahun 2004, 2005, dan 2006, ditemukan kejadian preeklampsia secara berturut-turut 8.140 kasus $(4,82 \%), 8.379$ kasus $(4,91 \%)$ dan 7.848 kasus $(5,8 \%)^{5-7}$ Penelitian lain menemukan kejadian preeklampsia di Indonesia berkisar antara 3\% - 10\% dan menyumbang $39,5 \%$ kematian maternal. ${ }^{8} \mathrm{Di}$ Rumah Sakit Umum PKU Muhammadiyah Yogyakarta tahun 2007- 2009 didapatkan 118 kasus preeklampsia atau sekitar $3,9 \%{ }^{9}$

Penyakit ini juga menimbulkan mortalitas yang cukup tinggi di Indonesia. Preeklampsia menyumbang kasus kematian sebanyak 145 kasus pada tahun 2004 dengan CFR 1,8\%, 197 kasus pada tahun 2005 dengan CFR 2,35\%, dan 166 kasus pada tahun 2006 dengan CFR 2,1\%. ${ }^{5-7}$ Data ini juga mendapatkan bahwa preeklampsia menempati posisi kedua penyebab terbanyak kematian maternal jika ditinjau dari jumlah kasus dan menempati posisi pertama jika ditinjau dari CFR. ${ }^{5-7}$

Preeklampsia dapat menimbulkan gangguan baik bagi janin maupun ibu. Kondisi preeklampsia dan eklampsia akan memberi pengaruh buruk bagi kesehatan janin akibat penurunan perfusi utero plasenta, hipovolemia, vasospasme, dan kerusakan sel endotel pembuluh darah plasenta. ${ }^{10}$ Dikatakan bahwa preeklampsia ini dapat menyebabkan intrauterine growth restriction/IUGR. Sebuah penelitian juga menemukan bahwa janin dari ibu yang mengalami preeklampsia, umumnya akan lahir dengan berat badan lahir rendah. ${ }^{11}$ Bahkan gangguan ini dapat berakibat kematian bagi janin. ${ }^{10}$ Pada maternal sendiri, akan timbul dampak buruk pada berbagai organ yang diakibatkan oleh vasospasme dan iskemia, terutama pada sistem kardiovaskuler, hemodinamik, hematologi, ginjal, hepar, otak dan sebagainya. ${ }^{12}$

Penyebab preeklampsia belum diketahui secara pasti. Ada beragam faktor risiko, di antaranya adalah faktor usia dan paritas yang merupakan faktor risiko yang tidak dapat dimodifikasi. Dari segi usia, wanita hamil dengan usia $<20$ tahun dan $>35$ tahun dianggap berisiko untuk mengalami preeklampsia. ${ }^{12}$ Hal ini disebabkan karena seiring peningkatan usia, akan terjadi proses degenaratif yang meningkatkan risiko hipertensi kronis dan wanita dengan risiko hipertensi kronik ini akan memiliki risiko yang lebih besar untuk mengalami preeklampsia. ${ }^{12}$ Berdasarkan data German Perinatal Quality Registry, didapatkan angka kejadian preeklampsia lebih tinggi pada usia di atas 35 tahun, yakni 2,6\%, dan pada usia di bawah 35 tahun hanya berkisar 2,2\% - 2,3\%. ${ }^{3}$ Di Rumah Sakit Dr. M. Djamil Padang, juga ditemukan kejadian preeklampsia lebih tinggi pada usia di bawah 20 tahun dan di atas 35 tahun. $^{13}$

Berdasarkan paritas, diyakini paritas 0 adalah faktor risiko preeklampsia, dimana kelainan ini lebih umum terjadi pada primigravida. ${ }^{9} \mathrm{Hal}$ ini diduga karena pada kehamilan pertama cenderung terjadi kegagalan pembentukan blocking antibodies terhadap antigen plasenta sehingga timbul respon imun yang tidak menguntungkan. ${ }^{9}$ Penelitian terhadap data German Perinatal QualityRegistry menemukan bahwa angka kejadian preeklampsia lebih tinggi pada kelompok paritas 0 atau kehamilan pertama, yakni $3,1 \%$, dibandingkan dengan pada kehamilan selanjutnya yang hanya $1,5 \% .^{3}$ Penelitian lain menemukan bahwa risiko terjadinya preeklampsia pada kehamilan pertama adalah $4,1 \%$, sedangkan akan berkurang pada kehamilan berikutnya menjadi $1,7 \% .{ }^{14}$

Meskipun secara teoritis dijelaskan bahwa terdapat hubungan usia dan paritas dengan preeklampsia, tetapi beberapa penelitian memperlihatkan hasil yang bertentangan dengan teori yang ada. Penelitian di Rumah Sakit Umum PKU Muhammadiyah Yogyakarta tahun 2007 menemukan bahwa preeklampsia justru lebih didominasi oleh 
kelompok usia 20-35 tahun. ${ }^{9}$ Penelitian di Rumah

Sakit Umum Dr. Saiful Anwar Malang juga menemukan bahwa tidak ada hubungan yang signifikan antara usia dengan preeklampsia. ${ }^{15}$ Penelitian yang pernah dilakukan di Jerman juga menemukan bahwa insiden preeklampsia pada wanita hamil dengan usia di bawah 20 tahun lebih rendah dibandingkan usia 20-35 tahun. ${ }^{3}$ Dari segi paritas, penelitian di Rumah Sakit Umum Daerah Kardinah Kota Tegal menemukan bahwa tidak ada hubungan yang bermakna antara paritas dengan preeklampsia. ${ }^{16}$ Penelitian di Rumah Sakit Dr. M. Djamil Padang juga mendapatkan hasil yang sama bahwa tidak terdapat hubungan antara paritas dengan preeklampsia. ${ }^{13}$

Penelitian ini dilakukan untuk menentukan apakah terdapat hubungan antara usia dan paritas dengan kejadian preeklampsia berat di Rumah Sakit Achmad Mochtar Bukittinggi.

\section{METODE}

Penelitian ini merupakan penelitian analitik dengan desain cross sectional study. Populasi pada penelitian ini adalah seluruh ibu hamil yang dirawat inap di Bangsal Obstetri dan Ginekologi Rumah Sakit Achmad Mochtar Bukittinggi. Sampel diambil secara totally sampling dengan jumlah sampel minimal dihitung berdasarkan rumus. Berdasarkan rumus sampel, didapatkan jumlah sampel minimal sebesar 356 sampel. Penentuan sampel didasarkan pada kriteria inklusi dan eksklusi. Kriteria inklusi penelitian ini adalah ibu hamil dengan usia kehamilan $\geq 20$ minggu dan memiliki catatan rekam medis yang memenuhi variabel yang diteliti. Kriteria eksklusi adalah ibu hamil dengan catatan rekam medis yang tidak lengkap, obesitas, diabetes melitus, riwayat penyakit ginjal dan riwayat hipertensi kronis.

Data yang didapat dikelompokkan menjadi tabel distribusi frekuensi dan tabel hubungan usia dengan preeklampsia berat. Data ini dianalisis dengan menggunakan ratio prevalence dan chi-square test dengan derajat kepercayaan $95 \%(\alpha=5 \%)$. Hipotesis diterima jika nilai $p<0,05$.
HASIL

Didapatkan populasi pasien rawat inap di Bangsal Obstetri dan Ginekologi Rumah Sakit Achmad Mochtar Bukittinggi selama tahun 2012 - 2013 sebanyak 3.248 pasien, yakni 1.687 pasien pada tahun 2012 dan 1.561 pasien pada tahun 2013. Dari populasi ini, dipilihlah sampel penelitian yang didasarkan pada kriteria inklusi dan eksklusi. Didapatkan jumlah sampel sebanyak 2.096. Hal ini berarti bahwa jumlah sampel yang didapatkan telah memenuhi syarat jumlah sampel minimal. Data yang dikumpulkan, juga didapatkan jumlah kasus preeklampsia berat selama tahun 2012 - 2013 sebanyak 162 kasus (4,99\%).

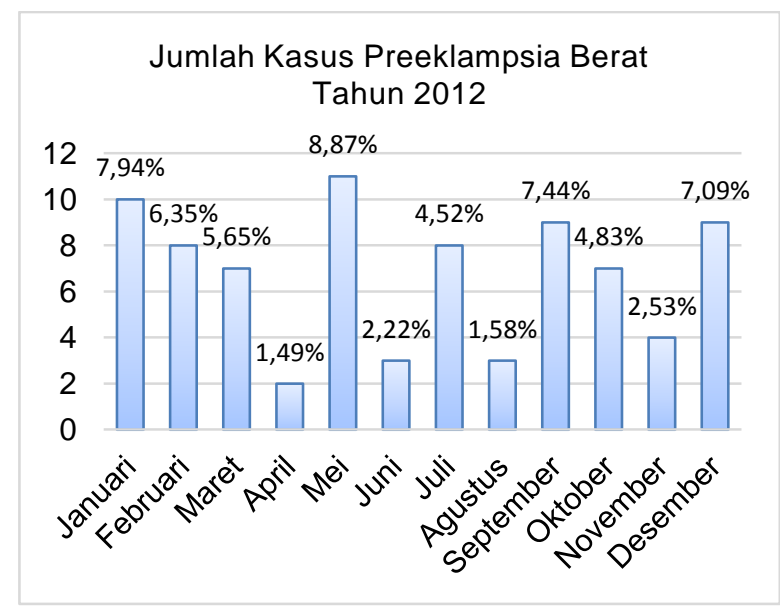

Gambar 1. Grafik jumlah kasus preeklampsia berat tahun 2012

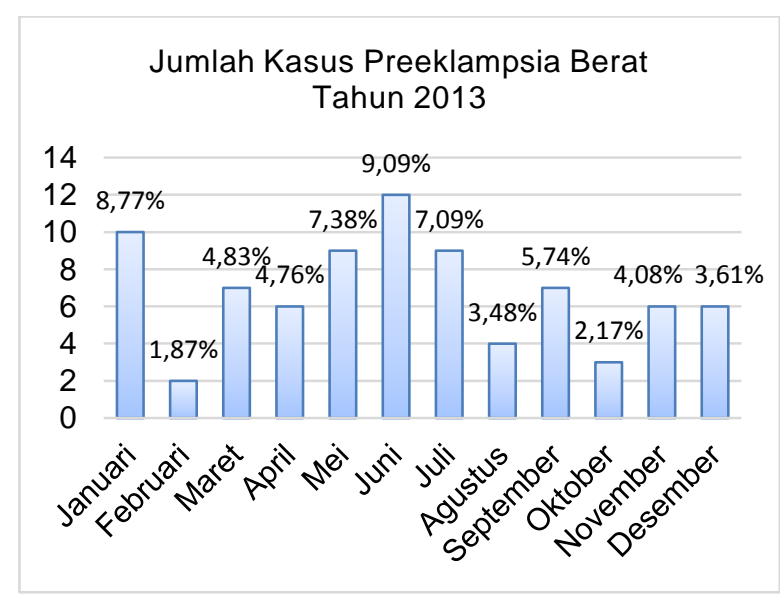

Gambar 2. Grafik jumlah kasus preeklampsia berat tahun 2013 
Berdasarkan Gambar 1 dan 2, dapat dilihat bahwa jumlah kasus preeklampsia mengalami perubahan setiap bulannya. Gambar 1 memperlihatkan bahwa pada tahun 2012 kasus terbanyak ditemukan pada bulan Mei, yakni 11 kasus (8,87 \%). Gambar 2 juga menggambarkan pada tahun 2013 kasus terbanyak ditemukan pada bulan Juni, yakni 12 kasus (9,09\%). Secara keseluruhan, kasus terbanyak terjadi pada bulan Juni 2013.

Tabel 1. Distribusi frekuensi preeklampsia berat berdasarkan usia

\begin{tabular}{ccc}
\hline Usia (tahun) & $\mathbf{f}$ & $\%$ \\
\hline$<20 \&>35$ & 66 & $40,74 \%$ \\
$20-35$ & 96 & $59,26 \%$ \\
\hline Jumlah & 162 & $100 \%$ \\
\hline
\end{tabular}

Tabel 2. Hubungan usia dengan preeklampsia berat

\begin{tabular}{|c|c|c|c|c|c|c|c|}
\hline \multirow{2}{*}{$\begin{array}{c}\text { Usia } \\
\text { (Tahun) }\end{array}$} & \multicolumn{2}{|c|}{ PEB } & \multirow{2}{*}{$\Sigma$} & \multirow{2}{*}{$\begin{array}{l}\text { Proporsi } \\
\text { PEB (\%) }\end{array}$} & \multirow{2}{*}{ p } & \multirow{2}{*}{$\mathbf{R P}$} & \multirow{2}{*}{$\mathrm{Cl}$} \\
\hline & + & - & & & & & \\
\hline$<20 \&>35$ & 66 & 600 & 666 & 9,90 & 0014 & 1470 & $1,094-$ \\
\hline 20-35 & 96 & 1334 & 1430 & 6,71 & 0,014 & & 1,922 \\
\hline$\Sigma$ & 162 & 1934 & 2096 & & & & \\
\hline
\end{tabular}

Subjek penelitian dengan usia terendah adalah usia 14 tahun dan usia tertinggi adalah usia 46 tahun. Pada Tabel 2 dapat dilihat bahwa terdapat 666 sampel pada kelompok usia $<20$ tahun dan $>35$ tahun. Hal ini menunjukkan masih tingginya angka kehamilan pada usia yang rentan tersebut.

Berdasarkan Tabel 1, dapat dilihat bahwa dari 162 kasus preeklampsia berat, 66 kasus (40,74\%) di antaranya adalah kelompok ibu hamil dengan usia $<20$ tahun dan $>35$ tahun dan 96 kasus $(59,26 \%)$ di antaranya adalah kelompok ibu hamil dengan usia 20 35 tahun. Hal ini menunjukkan bahwa dari seluruh kasus preeklampsia berat, kelompok usia terbanyak adalah usia 20 - 35 tahun. Jika ditinjau berdasarkan proporsi kejadian preeklampsia berat pada setiap kelompok usia (Tabel 2), maka proporsi preeklampsia berat terbanyak ditemukan pada kelompok usia <20 tahun dan $>35$ tahun dengan proporsi 9,09\%. Proporsi preeklampsia berat pada pada kelompok usia 20-35 tahun adalah $6,71 \%$.
Analisis statistik dengan chi-square test dan ratio prevalence. Berdasarkan perhitungan ratio prevalence, disimpulkan bahwa usia $<20$ tahun dan >35 tahun merupakan faktor risiko dari preeklampsia berat $(\mathrm{RP}=1,476 ; \mathrm{Cl}=1,094-1,922)$. Hasil chi-square test, didapatkan bahwa terdapat hubungan antara usia dengan preeklampsia berat $(p=0,014)$.

Tabel 3. Distribusi frekuensi preeklampsia berat berdasarkan paritas

\begin{tabular}{ccc}
\hline Paritas & $\mathbf{f}$ & $\%$ \\
\hline 0 & 65 & $40,12 \%$ \\
$\geq 1$ & 97 & $59,88 \%$ \\
\hline Jumlah & 162 & $100 \%$ \\
\hline
\end{tabular}

Tabel 4. Hubungan paritas dengan preeklampsia berat

\begin{tabular}{cccccccc}
\hline \multirow{2}{*}{ Paritas } & \multicolumn{2}{c}{ PEB } & & $\begin{array}{c}\text { Proporsi } \\
\text { PEB (\%) }\end{array}$ & $\mathbf{p}$ & $\mathbf{R P}$ & $\mathbf{C l}$ \\
\cline { 2 - 6 } & + & - & & PEB (\%) & & & \\
\hline 0 & 65 & 914 & 979 & 6,64 & & $0,565-$ \\
$\geq 1$ & 97 & 1020 & 1117 & 8,68 & & & 1,034 \\
\hline$\Sigma$ & 162 & 1934 & 2096 & & & & \\
\hline
\end{tabular}

Berdasarkan Tabel 3, dapat dilihat bahwa dari 162 kasus preeklampsia berat, 65 kasus (40,12\%) di antaranya adalah kelompok paritas 0 , dan 97 kasus $(59,88 \%)$ di antaranya adalah kelompok paritas $\geq 1$. Hal ini menunjukkan bahwa dari seluruh kasus preeklampsia berat, kelompok paritas terbanyak adalah kelompok paritas $\geq 1$. Berdasarkan proporsi kejadian preeklampsia berat pada setiap kelompok paritas, kejadian preeklampsia berat tetap didominasi oleh kelompok paritas $\geq 1$ dengan proporsi 8,68\%.

Pembuktian hubungan paritas dengan preeklampsia berat, dilakukanlah uji statistik dengan chi-square test dan ratio prevalence. Berdasarkan ratio prevalence, disimpulkan bahwa belum dapat ditentukan apakah paritas 0 merupakan faktor risiko atau faktor protektif dari preeklampsia berat $(\mathrm{RP}=$ 0,765; $\mathrm{Cl}=0,565-1,034)$. Chi-square test menunjukkan tidak terdapat hubungan antara paritas dengan preeklampsia berat $(p=0,096)$. 


\section{PEMBAHASAN}

Berdasarkan penelitian yang dilakukan, didapatkan angka kejadian preeklampsia berat sebanyak 162 kasus (4,99\%) dari 3.248 populasi pasien rawat inap di Bangsal Obstetri dan Ginekologi Rumah Sakit Achmad Mochtar Bukittinggi. Angka ini tidak jauh berbeda dengan data dari Profil Kesehatan Indonesia pada tahun 2004, 2005 dan 2006, yakni secara berturut-turut sebesar 4,82\%, 4,91\% dan $5,8 \%{ }^{5-7}$ Sebuah penelitian juga menemukan angka kejadian preeklampsia di Indonesia berkisar antara 310\%. ${ }^{8}$ Penelitian di Rumah Sakit Atma Jaya tahun 2009 - 2011 mendapatkan jumlah kasus preeklampsia yang tidak jauh berbeda, yakni 6,3\%. ${ }^{17}$ Penelitian yang dilakukan di Rumah Sakit Umum PKU Muhammadiyah Yogyakarta pada tahun 2007 - 2009 mendapatkan angka kejadian preeklampsia yang sedikit lebih rendah, yakni 3,9\%. ${ }^{9}$ Di Sumatera Barat sendiri, pernah dilakukan penelitian yang sama di Rumah Sakit Dr. M. Djamil Padang tahun 2004 - 2005 dan mendapatkan hasil yang sedikit lebih rendah, yakni $3,56 \%{ }^{13}$ Terdapatnya variasi angka kejadian preeklampsia dapat disebabkan karena perbedaan proporsi dari masing-masing faktor risiko di setiap penelitian, seperti faktor usia, paritas, obesitas, diabetes melitus, dan sebagainya.

Lonjakan kasus preeklampsia pada bulan Mei 2012 dan Juni 2013 disebabkan oleh peningkatan jumlah kehamilan pada bulan tersebut, mengingat preeklampsia tidak akan berkembang tanpa adanya kehamilan.

Berdasarkan Tabel 1, dapat dilihat bahwa dari 162 kasus preeklampsia berat, 96 kasus $(59,26 \%)$ di antaranya merupakan kelompok usia 20 - 35 tahun. Hal ini berarti bahwa dari seluruh kasus, kelompok usia yang dominan adalah kelompok usia 20 - 35 tahun yang bukan merupakan faktor risiko.Penelitian yang pernah dilakukan di Rumah Sakit Dr. $\mathrm{H}$. Soewondo Kendal juga mendapatkan hasil bahwa preeklampsia berat lebih dominan terjadi pada kelompok usia 20 - 35 tahun, yakni sebanyak 78 kasus (78\%), sedangkan pada kelompok usia <20 tahun dan >35 tahun hanya sebanyak 22 kasus $(22 \%){ }^{18}$ Hasil yang sama juga didapatkan pada penelitian di Rumah Sakit Umum Daerah Kardinah
Kota Tegal tahun 2011, dimana preeklampsia berat didominasi pada kelompok usia 20 - 35 tahun, yakni sebanyak 52 kasus (62,5\%). ${ }^{16}$ Penelitian di Rumah Sakit Umum Dr. Saiful Anwar Malang juga mendapatkan hasil yang sama, dimana kejadian preeklampsia berat lebih banyak terjadi pada kelompok usia 20 - 35 tahun, yakni 19 kasus(61,3\%). ${ }^{15}$ Begitu juga penelitian yang pernah dilakukan di Rumah Sakit Dr. M. Djamil Padang tahun 2004 - 2005, dimana didapatkan angka kejadian preeklampsia didominasi pada kelompok usia 20 - 35 tahun, yakni $67,68 \%$. $^{13}$ Terdapatnya perbedaan data ini dengan teori yang ada dapat disebabkan karena perbedaan jumlah sampel pada kedua kelompok usia, dimana sampel pada kelompok usia 20 - 35 tahun jauh lebih banyak. Untuk itu perlu dilihat proporsi kejadian preeklampsia berat pada setiap kelompok usia. Pada usia <20 tahun dan >35 tahun, didapatkan proporsi preeklampsia berat sebesar 9,90\%, sedangkan pada kelompok usia 20 - 35 tahun didapatkan proporsi preeklampsia berat sebanyak $6,7 \%$. Hal ini berarti bahwa proporsi preeklampsia berat terbanyak adalah apada kelompok usia <20 tahun dan >35 tahun, dan hasil yang didapatkan ini sesuai dengan teori yang ada.

Kebermaknaan hubungan usia dengan preeklampsia berat diuji dengan ratio prevalence dan chi-square test. Hasil analisis didapatkan bahwa ada hubungan antara usia dengan preeklampsia berat $(p=0,014)$ dengan usia $<20$ tahun dan $>35$ tahun adalah faktor risiko $(\mathrm{RP}=1,476 ; \mathrm{Cl}=1,094-1,922)$.

Berdasarkan Tabel 3, dapat dilihat bahwa dari 162 kasus preeklampsia berat, 97 kasus $(59,88 \%)$ di antaranya adalah kelompok paritas $\geq 1$, ini berarti bahwa preeklampsia berat lebih didominasi oleh kelompok paritas $\geq 1$ yang bukan merupakan faktor risiko. Sama halnya dengan faktor usia, karena terdapat perbedaan jumlah sampel pada kedua kelompok paritas, maka perlu dilihat proporsi kejadian preeklampsia berat pada kedua kelompok paritas. Namun, berdasarkan proporsi yang didapatkan, proporsi preeklampsia berat tetap lebih tinggi pada kelompok paritas $\geq 1$, yakni dengan proporsi $8,68 \%$. Hal yang sama juga didapatkan pada penelitian yang pernah dilakukan di Rumah Sakit Dr. M. Djamil 
Padang tahun 2004 - 2005, dimana frekuensi preeklampsia terbanyak ditemukan pada multipara, yaitu 64 kasus $(64,65 \%){ }^{13}$

Pembuktian kebermaknaan hubungan antara paritas dengan preeklampsia berat, dilakukanlah analisis statistik dengan ratio prevalence dan chisquare test. Dari analisis didapatkan bahwa tidak terdapat hubungan yang bermakna antara paritas dengan preeklampsia berat $(p=0,096)$ dan paritas 0 belum dapat ditentukan apakah merupakan faktor risiko atau faktor protektif $(\mathrm{RP}=0,765 ; \mathrm{Cl}=0,565-$ 1,034). Penelitian yang dilakukan di Rumah Sakit Umum Muhammadiyah Sumatera Utara tahun 20112012 juga menemukan bahwa tidak ada hubungan yang bermakna antara paritas dengan preeklampsia. ${ }^{19}$

Paritas 0 merupakan faktor risiko preeklampsia berat. Hal ini karena pada kehamilan pertama terjadi ketidaksempurnaan pembentukan blocking antibodies terhadap antigen plasenta, sehingga timbul respon imun yang tidak menguntungkan. ${ }^{9}$ Terdapatnya perbedaan antara hasil penelitian ini dengan teori dapat disebabkan oleh berbagai faktor. Di antaranya adalah terdapatnya sampel penelitian dengan paritas $\geq 1$ yang bukan kelompok faktor risiko, tetapi memiliki faktor risiko usia, yakni usia lebih dari 35 tahun. Di samping itu, terdapat juga kemungkinan kerancuan diagnosis preeklampsia, terutama pada wanita hamil yang tekanan darahnya sebelum hamil atau pada awal kehamilan tidak diketahui, serta tidak melakukan antenatalcare (ANC) rutin. Hal inilah yang menimbulkan kesulitan membedakan preeklampsia dan hipertensi kronik dengan superimposed preeklampsia. $^{12}$ Tidak diketahuinya keadaan tekanan darah sebelum kehamilan atau riwayat tekanan darah sebelumnya, maka hal ini juga akan menyebabkan keluputan dari proses eksklusi sampel untuk pasien yang mempunyai riwayat hipertensi yang tidak diketahui.

Desain penelitian cross sectional ini, tentunya terdapat kelebihan dan kekurangan. Pada penelitian dengan desain ini, pengumpulan data akan lebih cepat dan efisien, dan dengan demikian, penelitian ini dapat menggunakan jumlah sampel yang besar. ${ }^{20} \mathrm{Hal}$ ini berarti bahwa jumlah sampel yang dipilih akan sangat mewakili populasi yang ada. Dibandingkan dengan desain penelitian epidemiologi analitik lainnya, desain ini merupakan desain penelitian yang paling lemah. ${ }^{20}$ Pengambilan dan pengamatan data dilakukan pada saat yang bersamaan, maka hasil yang didapatkan tidak cukup untuk menentukan seberapa besar kekuatan hubungan antara variabel yang diteliti.

\section{KESIMPULAN}

Terdapat hubungan antara usia dengan preeklampsia berat dengan usia $<20$ tahun dan $>35$ tahun sebagai faktor risiko.

Tidak terdapat hubungan antara paritas dengan preeklampsia. Paritas 0 belum dapat ditentukan apakah merupakan faktor risiko atau faktor protektif.

\section{UCAPAN TERIMA KASIH}

Terima kasih kepada pihak-pihak yang terlibat dalam penelitian ini, terutama kepada seluruh staf di Bagian Diklat, Bagian Rekam Medis dan Bagian Obstetri dan Ginekologi Rumah Sakit Achmad Mochtar Bukittinggi, yang telah membantu semua proses pengambilan data penelitian.

\section{DAFTAR PUSTAKA}

1. Osungbade KO, Ige OK. Public health perspectives of preeclampsia in developing countries: implication for health system strengthening. J Pregnancy. 2011:1-2.

2. Guidotti R, Jobson D. Detecting pre-eclampsia: a partical guide. Geneva: WHO; 2005.

3. Schneider S, Maul H, Roehrig S, Fischer B, Hoeft B, Freerksen N. Risk groups and maternalneonatal complication of preeclampsia - current result from the National German Perinatal Quality Registry. J Perinat Med. 2001;39: 257-65.

4. Ananth CV, Keyes KM, Wapner RJ. Pre-eclampsia rates in the United States, 1980-2010: age period cohort analysis. BMJ. 2013: 3-4.

5. Departemen Kesehatan Republik Indonesia. Profil kesehatan Indonesia 2004. Jakarta: Depkes; 2006.

6. Departemen Kesehatan Republik Indonesia. Profil kesehatan Indonesia 2005. Jakarta: Depkes; 2007.

7. Departemen Kesehatan Republik Indonesia. Profil kesehatan Indonesia 2006. Jakarta: Depkes; 2008. 
8. Sulistyowati S, Abadi A, Wijiati. Los class Ib (HlaG/Qa-2) MHC protein expression against HSP-70 and VCAM-1 profile on preeclampsia: an observation on experimental animal mus musculus with endothelial dysfunction model. Health Sci J. 2010;34:103-4.

9. Djannah SN, Arianti IS. Gambaran epidemiologi kejadian preeklampsia/eklampsia di Rumah Sakit Umum PKU Muhammadiyah Yogyakarta tahun 2007-2009. Bul Penel Sistem Kes. 2010;13:37982.

10. Prawirohardjo S. Ilmu kebidanan. Jakarta: PT Bina Pustaka Sarwono Prawirohardjo; 2010.

11. Davison JM, Homouth V, Jeyabalan A, Conrad KP, Karumanchi SA, Quaggin S, et al. New aspects in the pathophysiology of preeclampsia. J Am Soc Nephrol. 2004;15: 2440-1.

12. Cunningham FG, Gant NF, Leveno KJ, Gilstrap LC, Hauth JC, Wenstrom KD. Obstetri williams. Edisi ke-21. Alih Bahasa oleh Andry Hartono, Y. Joko Suyono, Brahm U. Pendit. Jakarta: EGC; 2005.

13. Desfiyanti. Hubungan paritas dan usia ibu terhadap terjadinya preeklampsia pada ibu melahirkan di Rumah Sakit Dr. M. Djamil Padang tahun 20042005 (skripsi). Padang: Universitas Andalas; 2006.
14. Diaz SH, Toh S, Cnattingius S. Risk of preeclampsia in first and subsequent pregnancies: prospective cohort study. BMJ. 2009:2-3.

15. Rahayu ID. Hubungan usia dan paritas dengan kejadian preeklampsia di rawat inap SMF Obstetri Ginekologi Rumah Sakit Umum Dr. Saiful Anwar Malang (skripsi). Malang: Universitas Brawijaya; 2012.

16. Indriani N. Analisis faktor-faktor yang berhubungan dengan preeklampsia/ eklampsia pada ibu bersalin di Rumah Sakit Umum Daerah Kardinah Kota Tegal tahun 2011 (skripsi). Jakarta: Universitas Indonesia; 2012.

17. Khusen D, Polim AA. Factors influencing maternal mortality from severe preeclampsia and eclampsia. Indones J Obstet Gynecol. 2012;36:90-4.

18. Rozikhan. Faktor-faktor risiko terjadinya preeklampsia berat di Rumah Sakit Dr. H. Soewondo Kendal (tesis). Semarang: Universitas Diponegoro; 2007.

19. Resmi AS, Asfriyati, Lubis RM. Faktor yang berhubungan dengan preeklampsia pada kehamilan di Rumah Sakit UmumMuhammadiyah Sumatera Utara Medan tahun 2011-2012. GKRE. 2013; 2:1-10.

20. Kasjono HS, Kristiawan HB. Intisari epidemiologi. Yogyakarta: Mitra Cendikia Offset; 2008. 